\title{
Major Approaches towards Understanding Smart Cities Concept
}

\author{
Guzel Ishkineeva ${ }^{1}$, Farida Ishkineeva ${ }^{1} \&$ Simbul Akhmetova ${ }^{1}$ \\ ${ }^{1}$ Kazan Federal University, Kazan, Russia Federation \\ Correspondence: Farida Ishkineeva, Kazan Federal University, 18 Kremlyovskaya St., Kazan 420008, Republic \\ of Tatarstan, Russian Federation. Tel: 7-843-233-7109. E-mail: farida1967@mail.ru
}

Received: August 24, 2014 Accepted: November 20, 2014 Online Published: February 12, 2015

doi:10.5539/ass.v11n5p70 URL: http://dx.doi.org/10.5539/ass.v11n5p70

\begin{abstract}
The concept of "Smart city" which has become popular nowadays has no unambiguous interpretation. There is still no clear understanding of the meaning of this phenomenon, of its main characteristics and conditions necessary for its realization.

According to one approach, the city can be determined as smart if it is fully equipped with information and communication technologies and rendering e-services to population. While another emphasize on complex city development, and consider the presence of ubiquitous information and communication technologies just as an instrument of harmonizing city development.

Modern smart city should not only be technologically developed but it should also provide a new better quality of life and create more opportunities for the harmonious life and development for its citizens. "Smart city" can become an effective instrument of turning the economy to intensive and sustainable, and become a possible solution of a conflict between artificial and natural habitat only with this approach. In that sense "smart city" is the only possibility of the future existence in the technologic society.
\end{abstract}

Keywords: civil society, e-government, e-services, information-communication technologies, smart city, sustainable city development

\section{Introduction}

The issue of sustainable city development is one of the most discussed and relevant issues in modern society. Existing urban eco-systems are becoming unstable and incapable of providing a citizen with comfortable life conditions, there is an increasing anthropogenic impact on transforming urban system. There are significant changes in citizen's mentality, values and demands and all of this lead to the creation of new city development programs. That's why there is a need to overview most of theoretical and practical approaches and to look for the new ways of solving of city's problems and provide the citizens with a new better life.

One of the most popular concepts in the last decade is the concept of the "Smart city".

\section{Hypothesis}

Only technical and technological improvements and ubiquitous implementation of information and communication technologies can't make the city smart. Just in case of systematic approach and structural institutional reforms of all of the fields of social life the transformation of the city to the smart city is possible.

\section{The Method}

Conceptual, infrastructural and integrative approaches were used during the analysis of the relevant literature for the construction of the model of "smart city".

Theoretical and methodological base of the research is presented as follows:

1) According to the structural-functional approach (Durkheim, Parsons, \& Beck) the realization of the smart city is perceived as a complex phenomena; 2) According to the institutional approach (Sorokin, Luhmann, \& Luckmann) a system of laws and regulations of the use of information and communication technologies was studied as a necessary factor of realization of the smart city concept.

The informational base of the research is the following: laws and regulations considering the use of information and communication technologies, the data of the periodical press (Russian Economic Journal, Economic matters, 
Expert, Journal of Urban Technology, The American Economic Review, Cities, Regional Science and Urban Economics and others), regional and municipal periodical press, Internet sources (official websites of federal, regional, and municipal public bodies; official websites of the under-research cities; websites of federal and regional government statistics' bodies; Internet-editions; online conferences; forums and blogs of Russian population).

\section{Discussion}

The concept of the smart city, appeared in the end of XX ${ }^{\text {th }}$ century, has its followers in XXI, it has a number of interpretations. There isn't yet an unambiguous interpretation of the smart city, its main characteristics and conditions in social science.

There is a number of approaches to the understanding of this phenomenon.

According to the conceptual perspective, smart city is the strategic approach connecting different aspects of the city development to one system, with the use of artificial intelligence, ICTs, social and ecological potential to develop the city and increase its competitiveness (Crom, 2013).

According to the infrastructural approach, smart city is the combination of smart networks; it is the new life quality with the use of innovational technologies, demanding economically and ecologically efficient use of urban systems (Agency of Urban Development, 2013). However, in the XXI ${ }^{\text {th }}$ century urban environment is determined not only by availability of traditional infrastructure (material resources), smart city demands smart decisions, providing breakthrough development.

According to the integration approach, smart city is an effective city, complex socio-technical model, including technological resources for the smart living, together with ecological standards, and also new behavioral standards (Agency of Urban Development, 2013). At the same time, determination of the city as smart is, often, connected to its technological readiness and the spread of e-services. This approach is the most explicitly presented in the works of American and European researchers of 1970-1980-ies (Graham \& Marvin, 1996) and a number of Russian researchers. At that time, the main purpose of the policy makers was infrastructural re-equipment of the city aiming for inserting ubiquitous technologies, and the key aspect was to create digital and intelligent city. In XXI ${ }^{\text {th }}$ century the concept of the city is also understood as the city providing a lot of the services in electronic way. This understanding of the smart city is being used not only in Russia, but also abroad, for instance "Smart Chicago" (Smart Chicago, 2014).

Nowadays, ambitious projects using modern technologies to develop the city are used worldwide. Municipal authorities are strongly interested in making the city smart, so they are developing the programs of shifting public services to electronic, they are widely inserting technologies on state and municipal levels, and they are promoting e-government program.

However, the analysis of Russian and foreign reality indicates that in many cases the use of ICTs in public and municipal management is limited to formal number of services. The potential of ICTs today is not clear from neither citizens' nor functionaries' prospective. The active implementation of ICTs arises the question of constitutional rights to personal information, and it can totally change the relations of the government and citizen, and it can switch governmental activity to simple service-rending, which becomes a danger to public relations, and statehood. Creation of a common database concerning all information about private life, income, family, property and the other aspects of person's life can become a source of danger and sensibility of safety in the society of totalitarian state and it may become a reason of manipulation and the synonym of the society of control. Implementation of ICTs with repeating stable practices and with stable institutes is not a promising idea (Ishkineeva, 2013). So, interpretation of the smart city only as a technological improvement is one-side interpretation which doesn't fully explain the concept.

There is an active discussion about the conditions necessary for the realization of the concept of smart city.

According to the recent researches of Russian and foreign scientists, smart city should not only be technologically developed but it should also become a place providing new quality of life for citizens, and creating opportunities for harmonious development of the city. The accent now is more often on the harmonious city development while technological readiness is just an instrument of reaching the harmony of the city development (Abreu et al., 2008; Ishkineeva, 2013). According to the experts, smart city is the long-term concept and technological approach, where the city is fulfilled with smart buildings, roads, logically developed transport, engineer and energetic nets.

Concluding all the mentioned above information considering smart city the following main threats necessary for the smart development of the city can be distinguished: 
1. Availability and effective use of network infrastructure in terms of increasing political and economical effectiveness, and provision of social and cultural city development. What demands uncontroversial legislative system, multiple and wide spread services for business, easily accessible housing and leisure services, as well as availability and prevalence of information and communication technologies (phones, cable television, computer networks, and internet-services). So the wired city becomes the source of development and a model to follow. (Komninos, 2002).

2. Business-led urban development becomes determining. This is the idea of neoliberal public space, where creation of the favorable conditions for business is the main source for the involvement of the new business and support of the currently existing business structures, consequently, the city in general.

3. Social inclusion of all the residents of the city in urban processes becomes crucial. So researchers and policy makers should pay attention to the crucial issue of equitable urban growth. This characteristic demands equal participation of all stakeholders either in urban planning, or in policy-making, either in current decisions, or in a long-term prospective.

4. The increasing value of technological and creative fields in the city infrastructure. This factor, together with social infrastructure, is the key factor in the city development (Florida, 2002). The idea of this approach is that with the increasing number of creative professions there is an increasing demand for creative staff. Employers are somehow prompting their employees to develop them, to increase creativeness, aiming to increase competitiveness of the company. So, according to the American researcher Richard Florida, cities willing to be effective should be interested in creating better facilities for creative class, since it's the forward of the city development. The idea of the leading role of creative class in the city development can be also found in the works of Holland economist Peter Nijkamp. According to him, the presence of the creative class is the reason of qualified work force migration (Nijkamp, 2008). The presence of qualified work force is the crucial factor for the city development and competitiveness in science intensive global economy.

5. The next essential factor is the presence of social and relational capital. Smart city is the city where society is capable to learn something, change and understand it and create a new knowledge (Coe et al., 2001). Well-established public relations, communications and interactions enabling accumulation, enriching and take them to the qualitatively new level with the use of relational capital, this is the other necessary aspect. Besides that, absorptive capacity of economics plays significant role in city development (Abreu, 2008), so it's necessary to know how to use technologies to make them effective. In our opinion, these factors can't be omitted, since if so, there are a number of negative consequences that might appear, among them: social polarization, which might lead to economical, spatial and cultural polarization; and all of that can negatively impact city development.

6. The other strategic component of the smart city that should be mentioned is social and economical stability. Today, when there is severe resources constraint and the key aspects of the city prosperity are among others tourism and natural resources, cautious and renewable use of natural resources becomes crucial. This aspect is strongly connected to the necessity of equitable and fair urban development, since adequate balance of city's strong aspects development and weak zones protection is the basis of sustainable city development (Sustainable development: the connection between economics, society, and environment, 2008).

7. The list but not last factor of the smart city is the presence of stable functioning institutions of civil society together with effective engagement and interaction between state and society and effective social control, which is especially significant in post totalitarian societies.

Smart city is a complex characteristic which means the development of the city from economical, ecological and sociological perspectives, the development of intellectual and absorptive capacity of the city, and necessary opportunities of its effective development with the smart management.

\section{Conclusions}

To sum up, smart city is the city where investments in human and social capital and in traditional and modern infrastructure provide sustainable city development and high quality of life with wise use of natural resources and with smart use of the city potential (human, ecological, economic, management, absorption, and marketing) based on the participative management.

Obviously, the launch of the smart city concept is crucial for modern cities which are planning their future favorable existence and development. Irrational city becomes ineffective, meaning noncompetitive, while the attractiveness of the city for its citizens, possible investors and partners is strongly connected with its competitiveness. 
Analyzing current situation, obviously governmental institutions and large business can effect city development and change its directions, and they may have become the avant-garde of implementation the concept of the smart city, however being given the right and necessary opportunities they are practically more interested in implementing the smart city only in the technological instrumental way quite often, which is the most convenient for them but it doesn't use the positive potential of the concept for the city itself. Smart city it's besides that a good opportunity of the partnership in the state and the private sectors. This partnership is economically efficient in the following: new working places are being created, there are significant improvements of ecological situation, and there is decreasing necessity of the waste use of energy. In other words, smart city is an effective instrument to make Russian economy intensive and sustainable, and a great opportunity of sustainable future development.

Only in accordance of all of the mentioned conditions the city can become smart; smart city is the city with effective networkable business climate, smart professions, and, which is the most important, smart and free people who are able to make decisions and participate in the urban life and development. Just in case of system, and complex approach to the smart city implementation there is an opportunity that instrumental capacities of ICTs will switch to totally new way of state management and will be a method building conceptually new city format.

\section{Acknowledgments}

The work was funded by the subsidy allocated to Kazan Federal University for the state assignment in the sphere of scientific activities.

\section{References}

Abreu, M., Grinevich, V., Kitson, M., \& Savona, M. (2008). Absorptive capacity and regional patterns of innovation, Research Report. DIUS RR-8-11, Cambridge MA: MIT.

Coe, A., Paquet, G., \& Roy, J. (2001). E-governance and smart communities: a social learning challenge. Social Science Computer Review, 19(1). http://dx.doi.org/10.1177/089443930101900107

Crom, E. (2014). Road map for smart Petersburg. Retrieved March 7, 2014, from http://spb.rbc.ru/daily/18/ 07/2011/606027.shtml

Florida, R. L. (2002). The rise of the creative class and how it's transforming work, leisure, community and everyday life (pp. 10-14). New York: Basic Books.

Graham, S., \& Marvin, S. (1996). Telecommunications and the city: Electronic spaces, urban place (pp. 96-100). London: Routledge. http://dx.doi.org/10.4324/9780203430453

Information materials of non-profit partnership “Agency of urban development”. Retrieved March 2, 2014, from http://city-smart.ru/

Information portal “Smart Chicago”. Retrieved March 2, 2014, from http://www.smartchicagocollaborative.org/ category/city-of-chicago/.

Ishkineeva, F. (2013). The role of information and communication technologies in organization of effective interaction between society and public institutions. II International scientific and practical conference "Mass Media - society and eductaion: the problems of mediascurity", 21(312), 254-257.

Komninos, N. (2002). Intelligent cities: Innovation, knowledge systems and digital spaces (pp. 20-22). London: Spon Press.

Maksimova, F. (2011). Smart economics: aims, purposes and perspectives. Retrieved September 20, 2014, from http://www.e-joe.ru/sod/sod_11_3.html

Nijkamp, P. (2008). Epluribus unum. Research Memorandum. VU University Amsterdam.

Resume of the report "Sustainable development: the connection between economics, society, and environment". Retrieved March 20, 2014, from http://www.oecd.org/insights/41774417.pdf

\section{Copyrights}

Copyright for this article is retained by the author(s), with first publication rights granted to the journal.

This is an open-access article distributed under the terms and conditions of the Creative Commons Attribution license (http://creativecommons.org/licenses/by/3.0/). 